\title{
A new genus of railroad-worm beetles from the Atlantic Rainforest from Brazil (Coleoptera: Phengodidae, Mastinocerinae)
}

\author{
André Silva Roza ${ }^{1,2,3}$ \& José Ricardo Miras Mermudes ${ }^{1,2,4}$ \\ 1 Universidade Federal do Rio de Janeiro (UFRJ), Instituto de Biologia (IB), Departamento de Zoologia, Laboratório de Entomologia. \\ Rio de Janeiro, RJ, Brasil. \\ 2 Universidade Federal do Rio de Janeiro (UFRJ), Museu Nacional, Programa de Pós-Graduação em Zoologia. Rio de Janeiro, RJ, Brasil. \\ 3 ORCID: http://orcid.org/0000-0003-0886-5159. E-mail: andreroza1993@gmail.com \\ 4 ORCID: http://orcid.org/0000-0003-2030-7483. E-mail: jrmermudes@gmail.com
}

\begin{abstract}
Here we describe a new genus, Cleidella gen. nov., and two new species, C. picea sp. nov. and C. silveirai sp. nov., all from Rio de Janeiro State, Brazil. The new genus is characterized by the interantennal distance subequal to scape length, antenna with 11 antennomeres, IV to $\mathrm{X}$ with two long symmetrical branches; mandibles long, projected and not crossed, pointed forward obliquely from head; maxillary palpi 4-segmented, last segment digitiform; labial palpi 2-segmented; posterior tentorial pit consisting of a single small fossa; elytron surpassing from the fourth to fifth abdominal segment, 3.3-3.9 $\times$ longer than wide; first tarsomere of protarsus with a ventral comb as long as the tarsomere length; wing with radial cell closed and transverse, vein $r 4$ interrupted; aedeagus with paramere symmetrical, apex unevenly round, toothed inward, with short and scarce bristles. We provide a key to Mastinocerinae genera with 11 antennomeres, as well as illustrations for the diagnostic features for this new genus and a key to its species.
\end{abstract}

Key-Words. Mountains; Morphology; Neotropical; Taxonomy.

\section{INTRODUCTION}

The American Phengodidae LeConte, 1861 are composed of 295 species and 37 genera from southern Canada to northern Chile-Argentina, being more specious in the Neotropical region (Costa \& Zaragoza-Caballero, 2010; Zaragoza-Caballero \& Hernández, 2014; Constantin, 2014, 2016; Roza et al., 2017, 2018; Roza \& Mermudes, 2019; VegaBadillo \& Zaragoza-Caballero, 2019; Vega-Badillo et al., 2020). In Brazil, 59 species and 15 genera are recorded (Roza et al., 2017, 2018; Roza \& Mermudes, 2019; Quintino, 2019). Recent studies of the Brazilian fauna have uncovered several new taxa in the family (e.g., Roza et al., 2017, 2018; Roza \& Mermudes, 2019), especially in the Atlantic Rainforest. This biome is one of the 25 hotspots of biodiversity on the planet, among the five higher rates of endemism (Myers et al., 2000). However, it is the eighth threatened-most biome of the world (Fisher \& Christopher, 2007), with only $11-12 \%$ of its original forest cover remaining (Ribeiro et al., 2009; Fundação SOS Mata Atlântica \& INPE, 2014).

The taxonomy of Phengodidae is not well resolved. Although keys to identification of the American genera exist (Zaragoza-Caballero \&
Hernández, 2014; Constantin, 2014; Roza et al., 2017, 2018; Roza \& Mermudes, 2019), only Zarhipis LeConte, 1881 was revised (Linsdale, 1964). Redescriptions, illustrations and a key to some species of Phengodes Illiger, 1807 from the USA (Wittmer, 1975) and Distremocephalus Wittmer, 1976 from Mexico (Zaragoza, 1986) also exist. Besides that, most of genera are impossible to be identified at species level.

Currently, the group has three subfamilies in the Americas: Phengodinae LeConte, 1881, Mastinocerinae Leng, 1920 and Penicillophorinae Paulus, 1973. No phylogenetic analysis was ever conducted in order to test the monophyly of any genus in the family, and some of them may prove not to be natural groups. The internal relation of the family is unresolved, as the subfamilies were shown to be para- or polyphyletic, presenting the need for an updated classification through future phylogenetic analyses (Zaragoza-Caballero \& Zurita-García, 2015). Additionally, the Middle East Cydistinae (two genera and seven species), previously an Elateroidea incertae sedis, were recently found to be the sister group of the American Phengodidae, based on molecular data, and included in the group as a subfamily (Kundrata et al., 2019).
Pap. Avulsos Zool., 2020; v.60.special-issue: e202060(s.i.).10 http://doi.org/10.11606/1807-0205/2020.60.special-issue.10 http://www.revistas.usp.br/paz http://www.scielo.br/paz

Edited by: Sônia A. Casari / Gabriel Biffi

Received: 18/10/2019

Accepted: 14/02/2020

Published: 04/03/2020
ISSN On-Line: 1807-0205

ISSN Printed: 0031-1049

ISNI: 0000-0004-0384-1825 
Mastinocerinae Leng, 1920 is presently composed of 28 genera in the entire American continent (ZaragozaCaballero \& Hernández, 2014; Roza et al., 2017, 2018; Roza \& Mermudes, 2019; Vega-Badillo et al., 2020). The group is morphologically diverse and badly defined, with no genera ever revised and several new taxa waiting to be described. Inside the variation in their morphology, the genera in Mastinocerinae may present antennae with 10 antennomeres (two genera), 11 antennomeres (four genera) or 12 antennomeres (22 genera). The four genera with 11 antennomeres are: Euryognathus Wittmer, 1976, Euryopa Gorham, 1881, Steneuryopa Wittmer, 1986 and Microphrixothrix Roza \& Mermudes, 2019. Here, we describe a new genus, the fifth with 11 antennomeres, and two new species. One species is from the Serra dos Órgãos, on the Serra do Mar Mountain range, and the other from the previous location, and also Ilha Grande, Angra dos Reis. Both localities are in the Atlantic Rainforest of Rio de Janeiro State, Brazil. We also present a key to the genera of Mastinocerinae with 11 antennomeres, and to the species of the new genus.

\section{MATERIAL AND METHODS}

\section{Study areas}

The Parque Nacional da Serra dos Órgãos (PARNASO) is located at the Serra do Mar mountain range, in the Atlantic Rainforest of Southeastern Brazil. It includes in totality an area of 20,030 ha, with altitudes from 200 to $2,263 \mathrm{~m}$, nested at the borders of four municipalities in the Rio de Janeiro State: Guapimirim, Magé, Petrópolis and Teresópolis (ICMBIO, 2008). Its phytophysiognomies include: lower montane forest (below $800 \mathrm{~m}$ ), montane forest (600 to $1,500 \mathrm{~m})$, high-montane forest (1,500 to 2,000 m) and the "Campos de altitude" (CA) or "Brazilian Páramos" (starting at 2,000 m) (Rizzini, 1954; Veloso et al., 1991; Safford, 1999). Its climate varies from hot and rainy summers to humid winters, when temperatures near freezing are found at the mountaintops (Flinte et al., 2009).

The Parque Estadual da Ilha Grande (PEIG) protects an area of 12,072 ha at Ilha Grande, a continental island in the Angra dos Reis municipality, Rio de Janeiro State. The PEIG ranges elevations from sea level to $1,031 \mathrm{~m}$, of which Pico da Pedra da Água (1,031 m) and Pico do Papagaio $(959 \mathrm{~m})$ stand out as the highest peaks. Its climate is rainy during all year, with the higher rates in the summer and lower in winter, with enough pluviosity to cause landslides on densely forested areas during summer. The park includes the following vegetation types: Dense Ombrophilous Forest, the Restinga and the Mangrove (INEA, 2010).

\section{Collection, dissection and terminology}

All specimens were collected by Malaise traps and preserved in $90 \%$ alcohol.
Specimens are deposited at Coleção Entomológica Prof. José Alfredo Pinheiro Dutra, Universidade Federal do Rio de Janeiro, Rio de Janeiro, Brazil (DZRJ) and Museu de Zoologia, Universidade de São Paulo, São Paulo, Brazil (MZSP). Terminology follows Costa et al. (1999), Costa \& Zaragoza-Caballero (2010) and Zaragoza-Caballero \& Zurita-García (2015). For hind wings, we follow KukalováPeck \& Lawrence (1993). Specimens with the abdomen dissected have their terminalia preserved in alcohol. Photographs and measurements were taken with a Leica DFC450 and Application Suite CV3 multifocus software. The photographs were edited using Adobe Photoshop and the figure plates were designed with Adobe Illustrator (Adobe Systems). Total length was given by the sum of head, thorax and abdominal lengths, because extracting only overall body size could be misleading due to pronotal and head declination. Specimens were cleaned with ultrasonic sound for scanning electron microscopy (SEM), which was made with a Carl Zeiss, FEG Sigma 300 VP. We generated the distributional maps using the software Quantum GIS 2.14.3 (QGIS Development Team, 2016).

\section{RESULTS}

\section{Systematics \\ Phengodidae \\ Mastinocerinae}

\section{Key to Mastinocerinae genera with 11 antennomeres}

Adapted from Zaragoza-Caballero \& Hernández (2014), with modifications on couplet 5 and the addition of two new couplets:

4. 11 antennomeres.............................................................................

5. Interantennal distance bigger than scape length.................................... 6

5'. Interantennal distance subequal to slightly smaller than scape length $6 \mathrm{~b}$

6. Antennal flabellae cylindrical; ventral combs on the first and second tarsomeres of protarsus and first tarsomere of mesotarsus

...Microphrixothrix Roza \& Mermudes, 2019

6. Antennal flabellae lanceolated; ventral combs on the first tarsomeres of pro- and mesotarsus

... $6 \mathrm{a}$

6a. Antennal flabellae from antennomeres IV-X; mandibles without an inner tooth Euryopa Gorham, 1881

6a'. Antennal flabellae from antennomeres IV-VIII, IX-X inflate and without flabellae; mandibles with an inner tooth Euryognathus Wittmer, 1976 6b. All tarsomeres without ventral combs .......... Steneuryopa Wittmer, 1986 $6 b^{\prime}$. First protarsomere with a ventral comb. Cleidella gen. nov.

\section{Cleidella gen. nov.}

Type species: Cleidella picea sp. nov.

Diagnosis: Body overall small, around $4 \mathrm{~mm}$ long (Figs. 1A-B); interantennal distance subequal to scape length (Figs. 1E, 2A); antenna with 11 antennomeres, IV-X with two long symmetrical branches, 2 to $8 \times$ the size of 
the respective antennomere (Fig. 1D); mandibles long, projected and not crossed, pointed forward obliquely from head (Fig. 1C); maxillary palpi 4-segmented, last segment digitiform; labial palpi 2-segmented (Fig. 1F); posterior tentorial pit consisting of a single small fossa (Figs. 1F, 2B-C); pronotum narrower than humeral distance (Fig. 1A); elytron surpassing from the fourth to fifth abdominal segment, 3.3-3.9x longer than wide, slightly convergent posteriorly and slightly thickened apically (Figs. 1A, 4A); first tarsomere of protarsus with ventral comb as long as the tarsomere length (Fig. 3B); claws simple, without any teeth (Fig. 3A); wing with radial cell closed and transverse, vein $\mathrm{r} 4$ interrupted (Fig. 4B); aedeagus with parameres symmetrical, apex unciform, toothed inward, with short and scarce bristles (Figs. 5C-H).

Description, male: Length: $3.2-4.7 \mathrm{~mm}$.

Head (Figs. 1C-F, 2): Head wider than long, with posterior margin posteriorly convergent, usually partially covered by pronotum, slightly wider than pronotum; an-

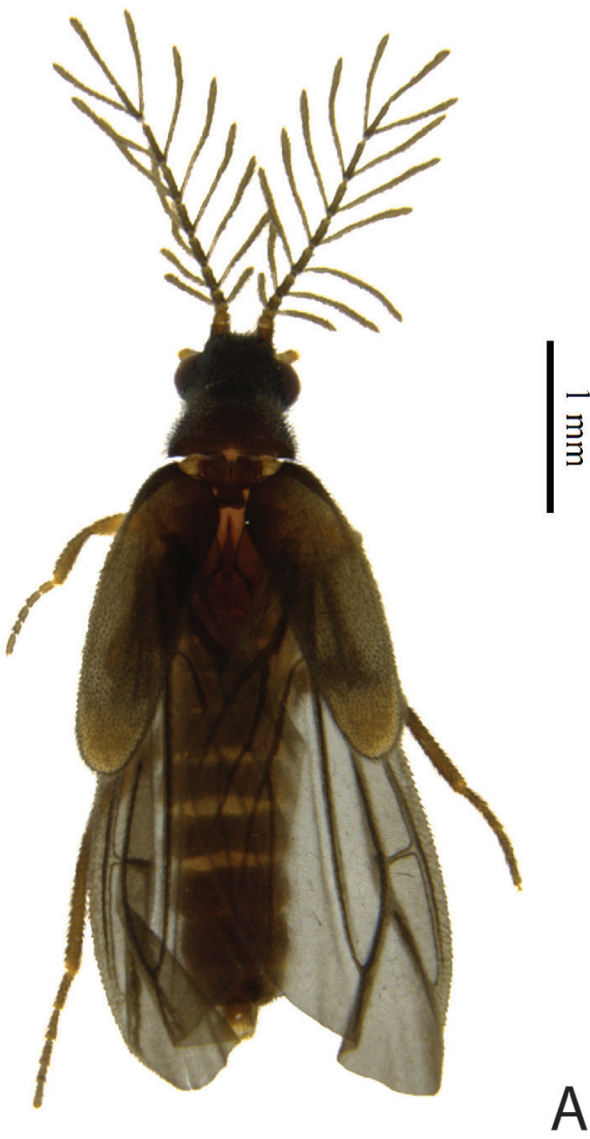

A

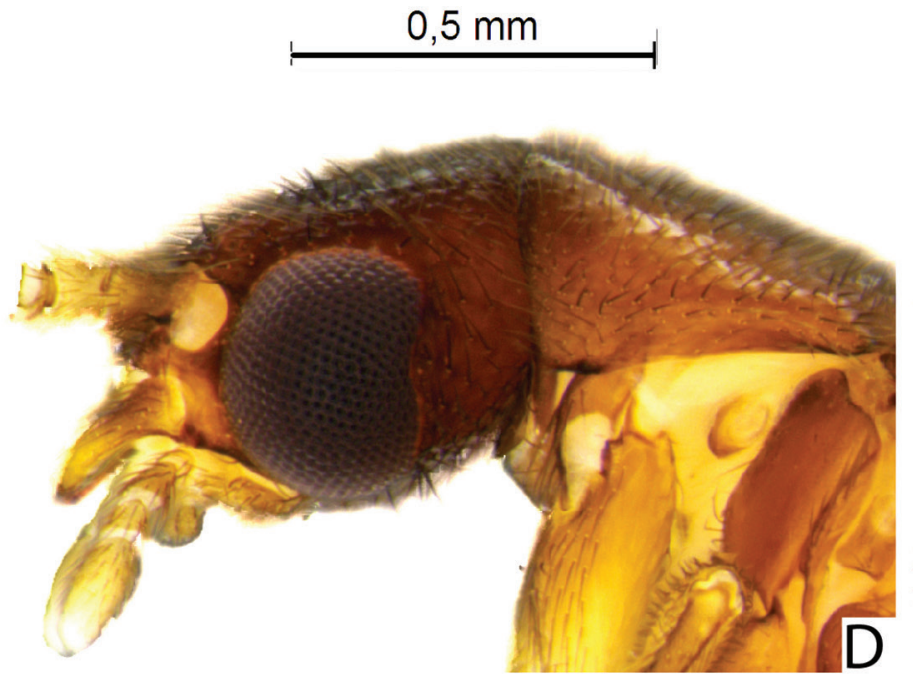

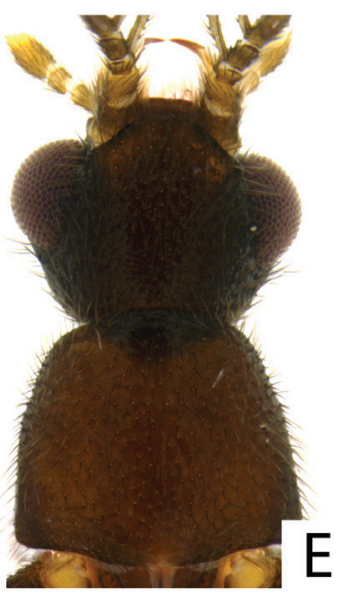

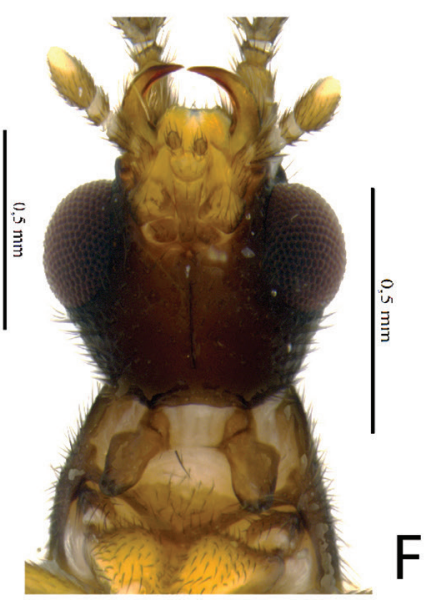

Figure 1. Cleidella picea gen. nov. et sp. nov., holotype male: (A) habitus, dorsal; (B) habitus, lateral; (C) head and pronotum, lateral; (D) antenna, lateral; (E) head and pronotum, dorsal; (F) head and prosternum, ventral. 
tenna longer than elytron; 11 antennomeres, IV-X each with two long, symmetrical branches, 2 to $8 \times$ longer than antennomere (Fig. 1D); eyes medium to large size, covering from $1 / 2$ to almost totally of head length in lateral view, finely faceted, laterally projected in dorsal view (Fig. 1E), posterior margin variable in lateral view; frons

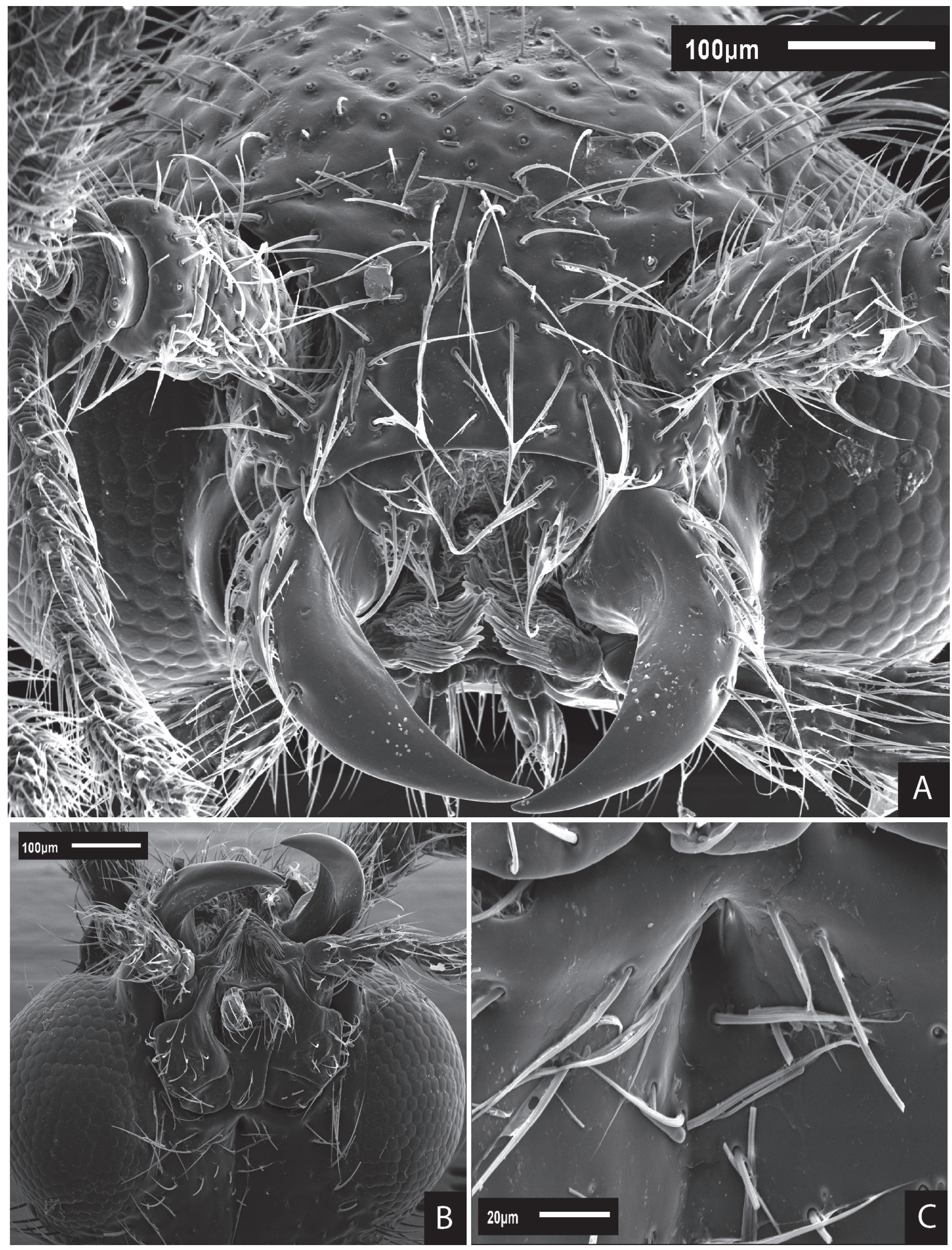

Figure 2. Cleidella picea gen. nov. et sp. nov., male, scanning electron micrographs: (A) head, frontal; (B) head, ventral; (C) tentorial pit, close. 
slightly convex between eyes, with a declivity between antennae until reaches labrum, interantennal space subequal to antennomere I length, clypeus fused to frons; labrum large, clearly separated from frontoclypeus, membranous, bilobate and swollen, with a pair of irregular latero-proximal slightly sclerotized pieces (Fig. 2A), as
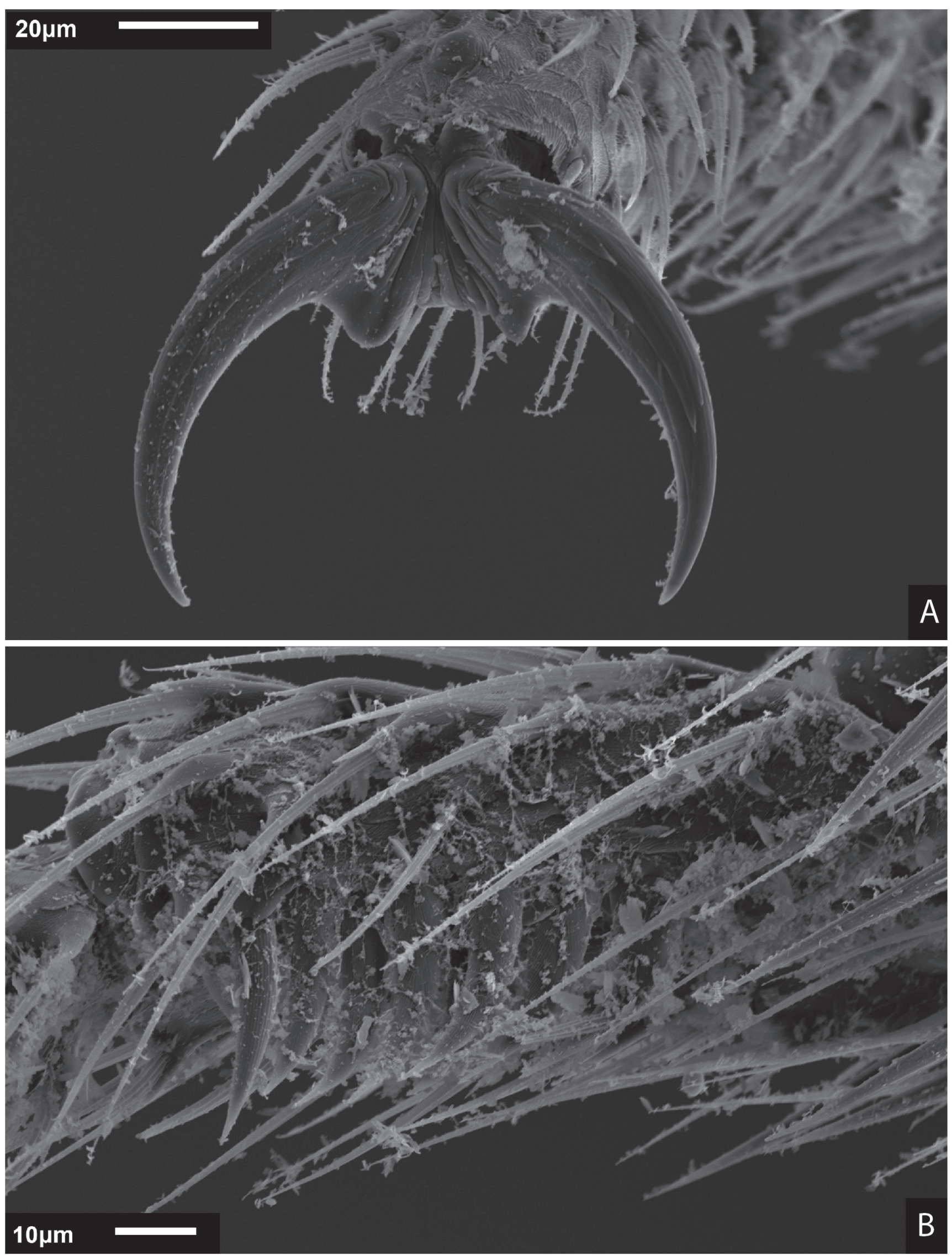

Figure 3. Cleidella picea gen. nov. et sp. nov., male, scanning electron micrographs: (A) protarsus, claw, frontal; (B) protarsus, protarsomere I, comb, ventral, close. 
wide as long; mandibles long and thin, projected and not crossed, pointed forward obliquely from head; maxillary palpi 4-segmented, palpomere II $2 \times$ longer than III, III as long as I, IV digitiform, $3 \times$ longer than III, coarsely punctate on anterior half, finely punctate on posterior half, cardo semitriangular, $1.5 \times$ wider than long; labial palpi 2-segmented, short, segment II $2 \times$ longer than I, not covered by mandibles, last palpomere digitiform; one gular suture, tentorial pit with single fossa (Figs. 2B-C, 2F), apodeme indistinct.

Thorax (Figs. 1E-F, 3-4): Pronotum trapezoidal, wider than long, anterior angles dorsally concave, lateral margins dorsally convergent from posterior to anterior angles, laterally curved down in anterior angles (Fig. 1E); elytron surpassing the fourth abdominal segment, 3.3-4x longer than wide, wider in anterior half, slightly convergent posteriorly, subparallel, apex slightly swollen (Figs. 1A, 4A); hind wings with radial cell closed, elongated and transversal, $\mathrm{r} 4$ interrupted both in the radial cell and $\mathrm{RP}, \mathrm{r} 3$ vestigial, RP reaching half of $M P 1+2$ length, medial field containing five main veins: MP3, MP4, CuA2 and $\mathrm{AA} 3+4 ; \mathrm{AA} 1+2, \mathrm{Cu} \mathrm{A} 1$ and $\mathrm{CuA} 3+4$ absent, $\mathrm{AA}$ well marked to vestigial and cubitoanal cell open or closed, anal lobe well developed, AP3+4 long, J absent (Fig. 4B); legs increasing in length, first tarsomere of protarsus with ventral comb as long as the tarsomere (Fig. 3B), first and second tarsomeres of protarsus subequal in length, third tarsomere longer, first, second and third tarsomeres of meso- and metatarsus increasing in length, fourth tarsomere of all legs with $1 / 2$ of the fifth length, claws without any teeth (Fig. 3A).

Abdomen (Fig. 5): Tergite IX transversal, divided in the middle, anterior margin curved inward, posterior margin nearly straight; tergite $\mathrm{X}$ short, conical, lateral margins subparallel (Fig. 5A); sternite IX short and quadrangular, curved inward in posterior margin (Fig. 5B); aedeagus with basal piece entirely sclerotized, ribbon-like; median lobe cylindrical, strongly curved at base, rounded and constricted apically, with many tiny glandular openings; flagellum encircled around median lobe at rest; about $1.5 \times$ longer than median lobe length; parameres parallel, symmetrical, narrowing slightly after middle towards apex, which is unciform, toothed inward, with short and scarce bristles separated by a distance at least twice the setae length (Figs. 5C-H).

\section{Female and immature stages: Unknown.}

Etymology: Singular genitive, feminine. The name is in honor of the entomologist Cleide Costa, in the commemoration of her 80th birthday. Professor Costa is a great researcher who greatly contributed to the knowledge of bioluminescent beetles, including phengodids, with a large focus on morphology and natural history.

Biology and distribution: Cleidella gen. nov. is only known from the Serra dos Órgãos, from 700 to $1,800 \mathrm{~m}$ of altitude, and in Ilha Grande, around $700 \mathrm{~m}$ of altitude, both in Rio de Janeiro State, Brazil. It is known to occur from spring to summer. No live specimens were observed to date, so there is no data regarding their habits.

Remarks: There are four described genera in Mastinocerinae with 11 antennomeres:Euryognathus, distributed in Venezuela, Paraguay and Argentina, Euryopa, distributed from Guatemala to Argentina, Steneuryopa, known from Costa Rica, and Microphrixothrix, known from Brazil. Cleidella gen. nov. can be easily separated from Microphrixothrix by the interantennal distance subequal to scape length (bigger in Microphrixothrix) and


Figure 4. Cleidella picea gen. nov. et sp. nov., male: (A) elytron, dorsal; (B) hind wing, dorsal 
the first tarsomere of protarsus with a ventral comb (first and second tarsomeres of protarsus and first tarsomere of mesotarsus with a ventral comb in Microphrixothrix).
It can be separated from the other three genera by the radial cell closed (open in all others). It also differs from Euryognathus by the cylindrical flabellae from antenno-
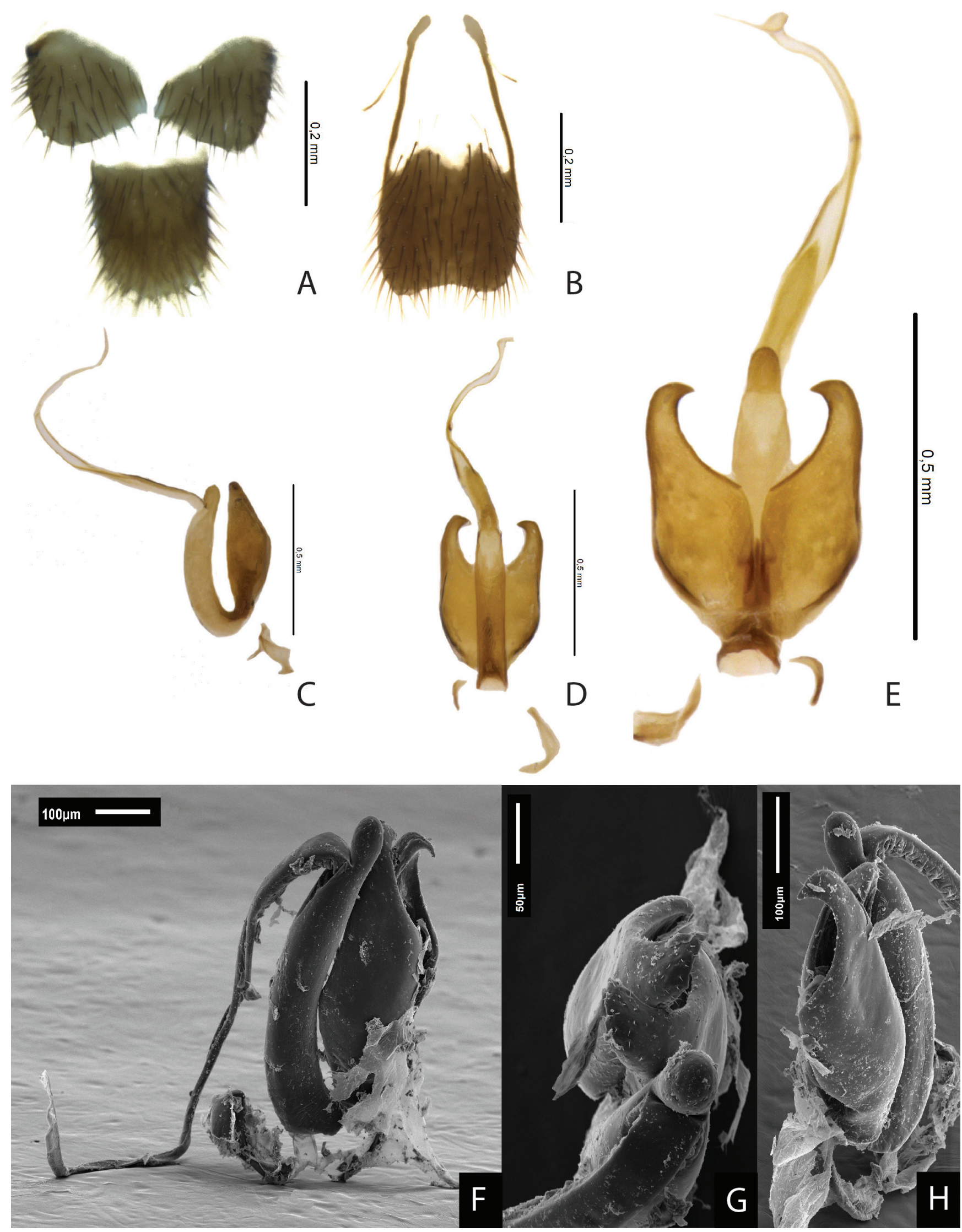

Figure 5. Cleidella picea gen. nov. et sp. nov., male: (A) Tergites IX and X, dorsal; (B) Sternite IX, ventral; (C) aedeagus, lateral; (D) aedeagus, ventral; (E) aedeagus, dorsal; Scanning electron micrographs: (F) aedeagus, lateral (G) aedeagus, frontal; (H) aedeagus, dorsolateral. 
meres IV-X (lanceolated from IV-VIII, IX-X inflate and without flabellae in Euryognathus), mandibles without teeth (toothed in Euryognathus), first tarsomere of protarsus with a ventral comb (first tarsomere of pro- and mesotarsus with a ventral comb in Euryognathus) and MP3 and MP4 present (absent in Euryognathus); from Euryopa by

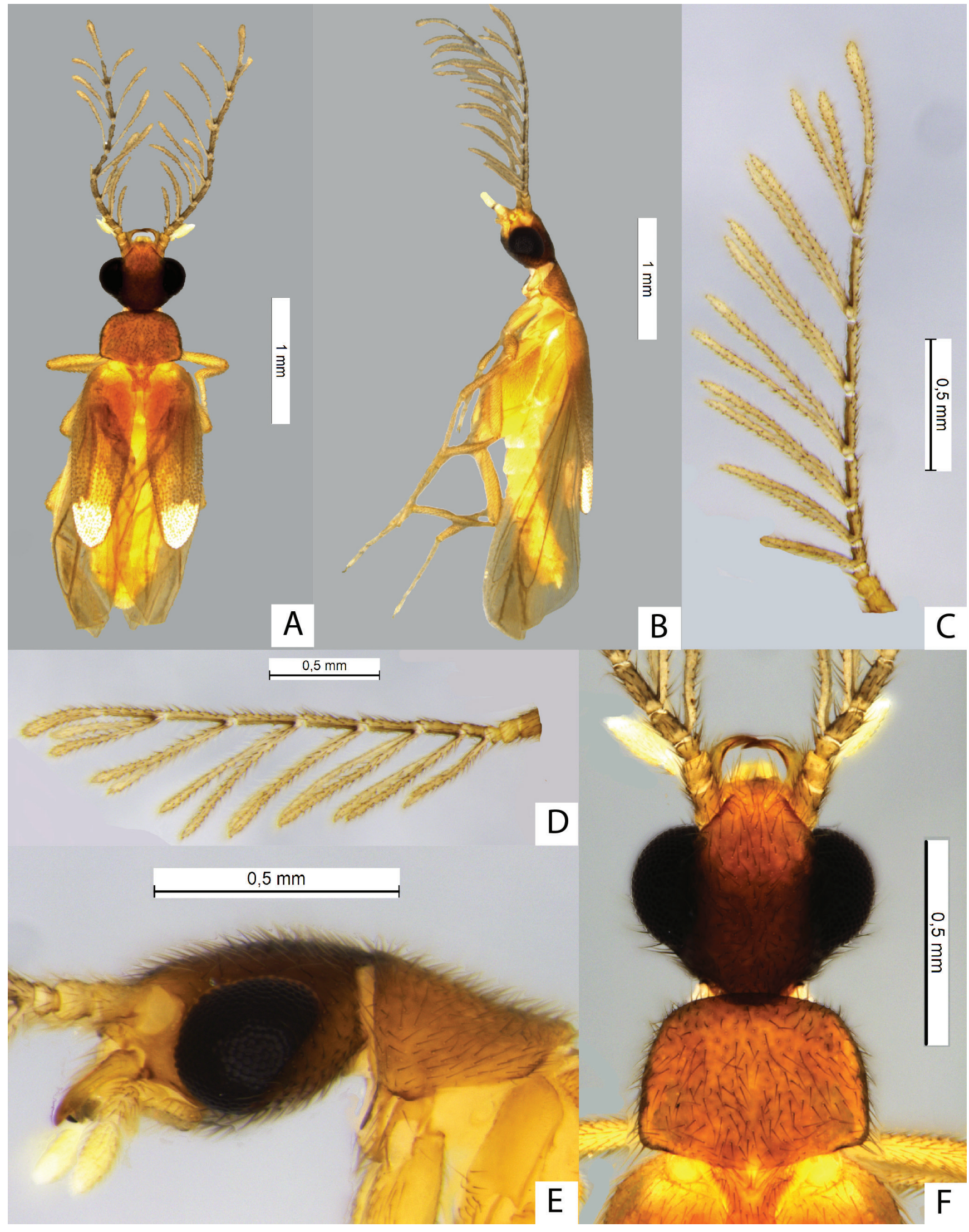

Figure 6. Cleidella silveirai gen. nov. et sp. nov., holotype male: (A) habitus, dorsal; (B) habitus, lateral; (C) antenna, specimen from Teresópolis; (D) antenna, specimen from Ilha Grande; (E) head and pronotum, lateral; (F) head and pronotum, dorsal. 
the cylindrical flabellae (lanceolated in Euryopa) and first tarsomere of protarsus with a ventral comb (the first tarsomere of pro- and mesotarsus with a ventral comb in Euryopa); and from Steneuryopa by the interantennal distance bigger than scape length (smaller in Steneuryopa), first tarsomere of protarsus with a ventral comb (without comb in Steneuryopa) and MP4 simple (bifurcated in Steneuryopa).

\section{Key to the species of Cleidella gen. nov.}

1. Body overall dark brown; eyes, in lateral view, with posterior margin vertical and slightly reniform (Fig. 1C); pronotum 1.1× wider than long (Fig. 1E) C. picea sp. nov.

1'. Body overall yellowish light-brown; eyes, in lateral view, with posterior margin strongly obliquely projected (Fig. $6 \mathrm{E}$ ); pronotum $1.4 \times$ wider than long (Fig. 6F). C. silveirai sp. nov.

\section{Cleidella picea sp. nov.}

(Figs. 1-5)

Type material: HOLOTYPE (o', DZRJ): BRAZIL. Rio de Janeiro: Teresópolis. Parque Nacional da Serra dos Órgãos. PVE Pt. 12A, $22^{\circ} 27^{\prime} 18,2^{\prime \prime} \mathrm{S}, 43^{\circ} 00^{\prime} 58,9^{\prime \prime} \mathrm{W}, 1,812 \mathrm{~m}$, IX.2015, R. Monteiro col. PARATYPES: Rio de Janeiro: Teresópolis. Parque Nacional da Serra dos Órgãos. PVE Pt. 9A, $22^{\circ} 26^{\prime} 55,1^{\prime \prime} \mathrm{S}, 43^{\circ} 00^{\prime} 16,4^{\prime \prime} \mathrm{W}, 1,246 \mathrm{~m}$, II.2015 (1 $\mathrm{o}^{\prime \prime}$,
DZRJ); PVE Pt. 9B, 22 $26^{\prime} 57.8^{\prime \prime} \mathrm{S}, 43^{\circ} 0^{\prime} 13.7^{\prime \prime} \mathrm{W}, 1,236 \mathrm{~m}$, II.2015, R. Monteiro col. (2 $0^{\circ}$, DZRJ).

Diagnosis: Eyes occupying nearly half of head width, in lateral view, posterior margin vertical, slightly reniform (Fig. 1C). Pronotum 1.1 $\times$ wider than long, anterior margin curved, posterior margin slightly curved (Fig. 1E). Body overall dark brown, with head and pronotum from black to dark brown, and mandibles, palpi and internal margin of pro- and mesocoxae and femora brown to light brown (Figs. 1A-B).

\section{Description, male}

Measurements $(\mathbf{n}=\mathbf{4})$ : Total length: $4.2-4.7 \mathrm{~mm}$ (aver. $4.4 \mathrm{~mm}$ ). Head length: 0.57-0.65 mm (aver. $0.6 \mathrm{~mm}$ ). Head width: 0.74-0.76 mm (aver. $0.75 \mathrm{~mm}$ ). Pronotum length: $0.62-0.65 \mathrm{~mm}$ (aver. $0.64 \mathrm{~mm}$ ). Pronotum maximum width: 0.71-0.76 (aver. $0.73 \mathrm{~mm}$ ). Elytron length: 1.80-1.85 mm (aver. $1.82 \mathrm{~mm}$ ). Elytron maximum width: 0.52-0.57 mm (aver. $0.54 \mathrm{~mm}$ ).

Morphology: Head wider than long, integument glossy, finely punctate, interocular distance occupying slightly more than half of head width in dorsal view (Fig. 1E); eyes occupying nearly half of head width, in lateral view, posterior margin vertical, slightly reniform (Fig. 1C); antennomere IV $2 \times$ longer than III, progressively longer from IV to $\mathrm{X}, \mathrm{XI}$ cylindrical, $1.5 \times$ longer than $\mathrm{X}$; IV-X each with two

Parque Nacional da Serra dos Órgãos (Teresópolis)



Figure 7. Distribution of Cleidella gen. nov. species. 
long, symmetrical branches, 2 to $8 \times$ longer than antennomere (Fig. 1D). Pronotum 1.1 $\times$ wider than long, integument glossy, finely punctate, anterior margin curved, lateral margins convergent in anterior half, dorsally parallel in posterior half, posterior margin slightly curved (Fig. 1F). Elytron heavily setigerous punctate, 3.1-3.5X longer than wide (Fig. 4A), reaching anterior margin of forth abdominal segment (Fig. 1B). Tergite IX transversal, twice wider than long in the middle line; tergite $X$ slightly longer than wide (Fig. 5A); sternite IX twice longer than wide when including membranous area, inner curved in the posterior margin (Fig. 5B). Aedeagus: basal piece entirely sclerotized, ribbon-like; median lobe cylindrical, strongly curved at base, rounded and constricted apically, with many tiny glandular openings; flagellum encircled around median lobe at rest; about $1.5 \times$ longer than median lobe length; parameres parallel, symmetrical, narrowing slightly past the middle towards the apex, which is unciform, toothed inward, with short and scarce bristles separated by a distance at least twice the seta length (Figs. 5C-H).

Coloration: Body overall dark brown, with head and pronotum from black to dark brown, and mandibles, palpi and internal margin of pro and mesocoxae and femora brown to light brown.

Females and immatures: Unknown.

Etymology: The specific name is a Latin adjective for "pitch-black" and refers to the dark overall color of the specimens' integument.

Biology and distribution: Cleidella picea sp. nov. occurs on the Spring and Summer of the southern hemisphere. It inhabits altitudinal areas of the Serra dos Órgãos, in the Serra do Mar mountain range, around 1,250-1,800 m, in a vegetation type of montane and high-montane forest.

Remarks: This species can be easily distinguished from Cleidella silveirai sp. nov. by the eyes, in lateral view, with posterior margin vertical, slightly reniform (strongly obliquely projected in $P$. silveirai sp. nov.); pronotum slightly wider than long (distinctly wider than long in $P$. silveirai sp. nov.); and the body overall dark brown, with head and pronotum from black to dark brown, and mandibles, palpi and internal margin of pro and mesocoxae and femora brown to light brown (body overall light brown, head brown, palpi, thoracic sterna, legs, tergites and sternites pale yellow in $P$. silveirai sp. nov.).

\section{Cleidella silveirai sp. nov.} (Fig. 6)

Type material: HOLOTYPE (o', DZRJ): BRAZIL. Rio de Janeiro: Teresópolis. Parque Nacional da Serra dos Órgãos. PVE Pt. 5B, 22 $28^{\prime} 37.6^{\prime \prime} \mathrm{S}, 42^{\circ} 59^{\prime} 45.5^{\prime \prime} \mathrm{W}, 691 \mathrm{~m}$, IX.2015, R. Monteiro col. PARATYPES: Rio de Janeiro: Teresópolis. Parque Nacional da Serra dos Órgãos. Same data as holotype, XII.2014 (1 $\sigma^{*}$, DZRJ, $1 \sigma^{\prime \prime}$, MZSP); PVE

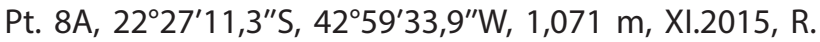
Monteiro col. (1 $\left.0^{\prime}, \mathrm{DZRJ}\right)$; Angra dos Reis. Parque Estadual

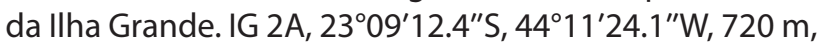

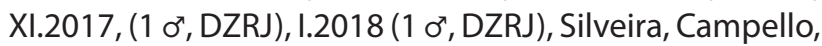
Vaz \& Queiroz col.

Diagnosis: Eyes, in lateral view, strongly obliquely projected (Fig. 6E). Pronotum 1.4x wider than long, anterior and posterior margins slightly curved to nearly straight (Fig. 6F). Body overall light brown, head brown, palpi, thoracic sterna, legs, tergites and sternites pale yellow (Figs. 6A-B).

\section{Description, male}

Measurements ( $\mathbf{n}=\mathbf{6}$ ): Total length: 3.2-3.6 mm (aver. $3.4 \mathrm{~mm}$ ). Head length: 0.47-0.53 mm (aver. $0.5 \mathrm{~mm}$ ). Head width: 0.62-0.67 mm (aver. $0.64 \mathrm{~mm}$ ). Pronotum length: 0.42-0.44 mm (aver. $0.43 \mathrm{~mm}$ ). Pronotum maximum width: 0.59-0.63 (aver. $0.6 \mathrm{~mm}$ ). Elytron length: $1.55-1.6 \mathrm{~mm}$ (aver. $1.57 \mathrm{~mm}$ ). Elytron maximum width: 0.39-0.48 mm (aver. $0.44 \mathrm{~mm}$ ).

Morphology: Head wider than long, integument glossy, finely punctate, frons slightly concave between antennal insertions, interocular distance occupying half of head in dorsal view (Fig. 6F); eyes occupying $3 / 4$ of head width, in lateral view, posterior margin strongly obliquely projected (Fig. 6E); antennomere IV 1.5-2x longer than III, progressively longer from IV to VIII, IX and X progressively shorter, XI cylindrical, 1.5-2X longer than X; IV-X with two symmetrical branches, 2 to $4 \times$ longer than antennomere (Fig. 6C-D). Pronotum 1.4x wider than long, integument glossy, finely punctate, anterior margin slightly curved, lateral margins weakly convergent, posterior margin slightly curved (Fig. 6F). Elytron heavily setigerous punctate, around $3.5 \times$ longer than wide (Fig. 6A), reaching posterior margin of fourth abdominal segment (Figs. 6A-B). Tergites IX and X, sternite IX and aedeagus shows no morphological variation in relation to $C$. picea sp. nov.

Coloration: Body overall light brown, head brown, palpi, sternum, legs, tergites and sternites pale yellow.

\section{Females and immatures: Unknown.}

Etymology: Patronymic. The name silveirai is given in honor of Luiz Felipe Lima da Silveira, a fellow coleopterist graduated from Universidade Federal do Rio de Janeiro, currently an assistant professor at the Western Carolina University, USA. Luiz is a Lampyridae specialist which also has interest in other soft-body Elateroid beetles, encouraging the first author to start the studies with Phengodidae. He has also collected extensively in areas of Rio de Janeiro state with Malaise traps.

Biology and distribution: Cleidella silveirai sp. nov. occurs on the Spring and Summer of the southern hemi- 
sphere. It inhabits altitudinal areas of the Serra dos Órgãos, in the Serra do Mar mountain range, around 700-1,100 m, in a vegetation type of montane forest, and altitudinal areas of Ilha Grande, around $700 \mathrm{~m}$, in a vegetation type of dense ombrophilous forest.

Remarks: This species can be easily distinguished from Cleidella picea sp. nov. by eyes, in lateral view, strongly obliquely projected (with posterior margin vertical, slightly reniform in C. picea sp. nov.); pronotum distinctly wider than long (slightly wider than long in C. picea sp. nov.); and the body overall light brown, head brown, palpi, thoracic sterna, legs, tergites and sternites pale yellow (body overall dark brown, with head and pronotum from black to dark brown, and mandibles, palpi and internal margin of pro and mesocoxae and femora brown to light brown in C. picea sp. nov.).

Two distinct populations of Cleidella silveirai sp. nov. were found, around $100 \mathrm{~km}$ apart from each other. The specimens from Ilha Grande have smaller flabellae in the antennae ( 2 to $3 \times$ the antennomere length) and the antennomere $\mathrm{XI} 1.5 \times$ the antennomere $\mathrm{X}$ length, while the specimens from the Serra dos Órgãos have longer flabellae in the antennae ( 3 to $4 \times$ the antennomere length) and the antennomere $\mathrm{XI} 2 \times$ the antennomere $\mathrm{X}$ length. However, as this was the only difference found between the populations, they were considered as a single species.

\section{DISCUSSION}

With a few exceptions, like in Phengodes or Zarhipis, most phengodid species have very narrow geographic ranges (Costa et al., 1999; Zaragoza-Caballero \& PérezHernández, 2014). Some features that might converge in explaining their restricted ranges include: soft body, apparently semelparous lifestyle (Tiemann, 1967) and poor flying ability. Together, these features render them sensitive to temperature and humidity variation at the microclimate scale, and subject to wind forces (see Viviani \& Bechara, 1997; Costa \& Zaragoza-Caballero, 2010). Moreover, all known phengodid females are apterous and larviform, which facilitate even more allopatric speciation events due to vicariance, a common phenomenon in beetle lineages with soft-bodies and larviform females (see Bocak et al., 2008).

The Atlantic Rainforest presents a complex system of mountain chains with altitudinal gradients of temperature, humidity, and vegetation cover. This variation from the surrounding lowlands towards mountaintops may drive local adaptation and ecological speciation, originating endemic taxa (reviewed in Hodkinson, 2005). These conditions may be especially influential on the evolutionary history and speciation of railroad-worms. This pattern of endemism has been observed in other soft-bodied elateroid beetles, such as lampyrids (e.g., Silveira et al., 2016) and phengodids (e.g., Roza et al., 2017).

The here-described new genus presents an interesting pattern of distribution, with two apparently isolat- ed populations of Cleidella silveirai sp. nov. around 100 $\mathrm{km}$ apart from each other. A similar pattern was found in two species of Akamboja Roza, Quintino, Mermudes \& Silveira (Roza et al., 2017, 2018). When compared with widespread species in other genera of Phengodidae (e.g., Zarhipis, Phrixothrix Olivier, 1909 and Stenophrixothrix Wittmer, 1963), both Cleidella gen. nov. and Akamboja stand out by their very short body length $(<5 \mathrm{~mm})$, which could prevent long distance dispersal. This isolation, however, could be a sampling bias (Roza et al., 2018), as most of rail-road worm species have their distribution only superficially known. Nonetheless, these aforementioned species are particularly interesting for phylogeographic studies, and future studies on genetic diversity and structuring may reveal the history behind such disjunct distribution.

\section{ACKNOWLEDGMENTS}

We would like to thank Gabriel Biffi and Sonia Casari (Museu de Zoologia, Universidade de São Paulo) for their invitation for this special issue and to the two anonymous reviewers for their comments and suggestions in this manuscript. Ricardo and Margarete Monteiro (Laboratório de Ecologia de Insetos/Universidade Federal do Rio de Janeiro, Brazil) for providing the samples from Teresópolis and Ilha Grande; the staff at Parque Nacional da Serra dos Órgãos and Parque Estadual da Ilha Grande for supporting the research in fieldwork; the staff at Laboratório de Ecologia delnsetos/UFRJand Laboratório de Entomologia/ UFRJ for field assistance; Marcelo Sales for operating SEM equipment at the Laboratório de Microscopia Eletrônica do Instituto de Biologia da Universidade Federal do Rio de Janeiro; Fundação de Amparo à Pesquisa do Estado do Rio de Janeiro (FAPERJ), for the photographic system acquired by through grants: Proc. 110.040/2014; $010.001641 / 2014$ and $111.247 / 2014$. ASR was funded by the Postgraduate program in Zoology at the Museu Nacional, Coordenação de Aperfeiçoamento de Pessoal de Nível Superior - Brasil (CAPES) - Finance Code 001, CNPq 06105/2016-0, and JRMM was funded by PROTAX CNPQ/CAPES 440479/2015-0; CNPq 306105/2016-0 and 311679/2019-6; FAPERJ 211.522/2016.

\section{REFERENCES}

Bocak, L.; Bocakova, M.; Hunt, T. \& Vogler, A.P. 2008. Multiple ancient origins of neoteny in Lycidae (Coleoptera): consequences for ecology and macroevolution. Proceedings of the Royal Society of London B: Biological Sciences, 275(1646): 2015-2023.

Constantin, R. 2014. Contribution à la connaissance des Phengodidae de Guyane et description de huit espèces nouvelles (Coleoptera, Elateroidea). Coléoptères de Guyane, 8: 86-104.

Constantin, R. 2016. Deux nouveaux Phengodidae de Guyane et du Guyana (Coleoptera, Elateroidea). Le Coléoptériste, 19(3): 158-162

Costa, C. \& Zaragoza-Caballero S. 2010. Phengodidae Le Conte, 1861. In: Leschen, R.A.B.; Beutel, R.G. \& Lawrence, J.F. (Eds.). Coleoptera, Beetles. Vol. 2: Morphology and systematics (Elateroidea, Bostrichiformia, 
Cucujiformia partim).; Berlin, Walter de Gruyter. p. 126-135. (Handbook of Zoology, Arthropoda: Insecta).

Costa, C.; Vanin, S.A.; Casari, S.A. \& Viviani, V.R. 1999. Larvae of Neotropical Coleoptera. XXVII. Phrixotrix hirtus: immatures, neotenic female, adult male and bionomic data (Phengodinae, Phengodidae, Coleoptera). Ilheringia. Serie Zoologia, 86: 9-28.

Fisher, B. \& Christopher, T. 2007. Poverty and biodiversity: measuring the overlap of human poverty and the biodiversity hotspots. Ecological economics, 62(1): 93-101.

Flinte, V.; Macedo, M.V. \& Monteiro, R.F. 2009. Chrysomelids and their host plants along an altitudinal gradient in an Atlantic Rain Forest in the State of Rio de Janeiro, Brazil. Research on Chrysomelidae, 2: 31-56.

Fundação SOS Mata Atlântica \& Instituto Nacional de Pesquisas Espaciais (INPE). 2014. Atlas dos remanescentes florestais da Mata Atlântica período 2012-2013. São Paulo, Fundação SOS Mata Atlântica/Instituto Nacional de Pesquisas Espaciais.

Hodkinson, I.D. 2005. Terrestrial insects along elevation gradients: species and community responses to altitude. Biological Reviews, 80(3): 489-513.

Instituto Chico Mendes de Conservação da Biodiversidade (ICMBio). 2008. Plano de manejo do Parque Nacional da Serra dos Órgãos. Brasília, Instituto Chico Mendes de Conservação da Biodiversidade.

Instituto Estadual do Ambiente (INEA). 2010. Plano de Manejo, Parque Estadual da llha Grande. Governo do Estado do Rio de Janeiro, Rio de Janeiro.

Kukalová-Peck, J. \& Lawrence, J.F. 1993. Evolution of the hind wing in Coleoptera. The Canadian Entomologist, 125(2): 181-258.

Kundrata, R.; Blank, S.M.; Prosvirov, A.S.; Sormova, E.; Gimmel, M.L.; Vondráček, D. \& Kramp, K. 2019. One less mystery in Coleoptera systematics: the position of (ydistinae (Elateriformia incertae sedis) resolved by multigene phylogenetic analysis. Zoological Journal of the Linnean Society, 187(4): 1259-1277.

Linsdale, D.D. 1964. A revision of the genus Zarhipis LeConte (Coleoptera: Phengodidae). The Wasmann Journal of the Biology, 22(2): 225-260.

Myers, N.; Mittermeier, R.A.; Mittermeier, C.G.; Fonseca, G.A.B. \& Kent, J. 2000. Biodiversity hotspots for conservation priorities. Nature, 403: 853-845.

QGIS Development Team. 2016. QGIS Geographic Information System. Open Source Geospatial Foundation Project. Available at: http://www.qgis.org/ en/site/index.html. Access in: 01/09/2016.

Quintino, H.Y.S. 2019. Phengodidae in Catálogo Taxonômico da Fauna do Brasil. PNUD. Available at: http://fauna.jbri.gov.br/fauna/ faunadobrasil/126405. Access in: 08/06/2019.

Ribeiro, M.C.; Metzger, J.P.; Martensen, A.C.; Ponzoni, F.J. \& Hirota, M.M. 2009. The Brazilian Atlantic Forest: How much is left, and how is the remaining forest distributed? Implications for conservation. Biological Conservation, 142(6): 1141-1153.

Rizzini, C.T. 1954. Flora organensis: lista preliminar dos Cormophyta da Serra dos Orgãos. Arquivos do Jardim Botânico do Rio de Janeiro, 13: 115-243.
Roza, A.S. \& Mermudes, J.R.M. 2019. New genus and two new species of railroad-worm beetles from Brazil, with a discussion on asymmetry of aedeagus in the family (Coleoptera: Phengodidae). Annales Zoologici, 69(4): 805-816.

Roza, A.S.; Mermudes, J.R.M. \& Silveira, L.F.L. 2018. New species and rediagnosis of Akamboja, and a new record for A. minimum (Coleoptera: Phengodidae, Mastinocerinae). Journal of Natural History, 52(45-46): 2935-2947.

Roza, A.S.; Quintino, H.Y.S.; Mermudes, J.R.M. \& Silveira, L.F.L. 2017. Akamboja gen. nov., a new genus of railroad-worm beetle endemic to the Atlantic Rainforest, with five new species (Coleoptera: Phengodidae, Mastinocerinae). Zootaxa, 4306(4): 501-523.

Safford, H.D. 1999. Brazilian páramos I. An introduction to the physical environment and vegetation of the campos de altitude. Journal of Biogeography, 26: 693-712.

Silveira, L.; Khattar, G.; Souto, P.; Mermudes, J.R.M.; Takiya, D.M. \& Monteiro, R.F. 2016. Integrative taxonomy of new firefly taxa from the Atlantic Rainforest. Systematics and Biodiversity, 14(4): 371-384.

Tiemann, D.L. 1967. Observations on the natural history of the western banded glowworm Zarhipis integripennis (LeConte) (Coleoptera: Phengodidae). Proceedings of the California Academy of Science, 35(12): 235-264.

Vega-Badillo, V. \& Zaragoza-Caballero, S. 2019. Especie nueva del género Phengodes (Phengodella) (Coleoptera: Phengodidae) y una clave para los fengódidos de Belice. Revista Mexicana de Biodiversidad, 90(1): e902863.

Vega-Badillo, V.; Zaragoza-Caballero, S. \& Ivie, M.A. 2020. A new genus of Phengodidae (Coleoptera) from the Neotropical Region. Papéis Avulsos de Zoologia, 60(Special Issue): 1-7, e202060(s.i.).06. DOI

Veloso, H.P.; Rangel-Filho, A.L.R. \& Lima, J.C.A. 1991. Classificação da vegetação brasileira adaptada a um sistema universal. Instituto Brasileiro de Geografia e Estatística (IBGE), Rio de Janeiro.

Viviani, V.R. \& Bechara, E.J. 1997. Bioluminescence and biological aspects of Brazilian railroad-worms (Coleoptera: Phengodidae). Annals of the Entomological Society of America, 90(3): 389-398.

Wittmer, W. 1975. The genus Phengodes in the United States (Coleoptera: Phengodidae). The Coleopterists'Bulletin, 29(4): 231-250.

Zaragoza-Caballero, S. \& Hernández, C.X.P. 2014. Sinopse de la familia Phengodidae (Coleoptera): trenecitas, bigotudos, glow-worms, rail-road worms, o besouros trem de ferro. Universidad Nacional Autónoma de México, México.

Zaragoza-Caballero, S. \& Zurita-García, M.L. 2015. A preliminary study on the phylogeny of the family Phengodidae (Insecta: Coleoptera). Zootaxa, 3947(4): 527-542.

Zaragoza, S.C. 1986. El genero Distremocephalus Wittmer en Mexico (Coleoptera: Phengodidae). Anales del Instituto de Biologia de la Universidad Nacional Autónoma de México, 56: 189-202. 